\title{
Contradicting Learning Environments between Rural and Urban: The Case of Malawi
}

\author{
Albert K. M. Y. Kayange \\ Unicaf University, Malawi
}

\begin{abstract}
Education is the strongest tool which enables people to live and progress to their supreme potential [27]. It is for this reason that education should be accessible to all and be of the highest quality if countries are to yield meaningful educational outcomes. Literature has indicated that rural learning environment in Malawi is contrary to urban ones despite of learners being treated equally when it comes to examinations and selection to higher learning institutions [23]. This paper was therefore compelled to look at contradicting educational learning environment between rural and urban learning institutions of both primary and secondary institutions. The critical emphasis was based on two areas: i. Quality and quantity of teaching staff and ii. Learner's environment. Based on the desk study, the findings disclosed that most rural scholars and teachers are denied of quality education environment. The lack of government and other educational players commitment to educational sector in terms of: Training teachers, teacher's welfare, learning infrastructures, teaching and learning materials and under or no funding contributes to poor rural educational misery. The paper finally makes recommendations on how best rural and urban education can have equal quality teaching and learning environment in order to yield progressive lives and potential developmental for the country and world at large.
\end{abstract}

Keywords: Quality education, human right, rural learning institution, Urban learning institutions.

\section{Introduction}

Education for All (EFA) and Millennium Development Goals [8] reiterates that Africa is certainly the least industrialized continent worldwide. Despite most African countries have made some developmental stride, the popular countries are still faced with developmental challenges, Malawi inclusive. UNDP [29] states that human capital is the basis for any developing nation to realize its developmental goals and as such, must invest in people for its industrialization and developmental vision. As the human development resources are threatened by poverty, it is more difficult for Africa to be bailed-out from its un- industrialization status. In most cases, there has been inequality in educational facilities and quality of infrastructures and teachers between rural and urban educational institutions because of the many countries' syndrome of prioritizing developmental agendas in urban and rural being after thought. The human development option should therefore be dynamic in education if countries developmental achievement is to be accomplished [19].

Mulkeen [21] has reiterated that poor school environment is the paramount obstacle to economical social and political transformation in most African states. An average of eighteen percent of primary pupils in African public institutions repeat once in a while a year due to poor teaching and scarcity of teaching and learning materials in particular, rural areas. Such repeaters normally between fourth to sixth classes cannot read nor write well [1]. Malawi's education is categorized into three namely: Basic education which is normally called primary; secondary education and tertiary education. Tertiary institutions are generally allocated in semi or urban areas while primary and secondary institutions are both of rural and urban. Taylor and Mulhall, [26] established in their research findings that there are more dynamics which contributes to educational dwindling participation in rural areas as compared to urban schools. There are therefore less country children interested in schooling than those in urban areas on the following grounds: The majority of Malawians (Over 80\%) live in rural areas where poverty is rampart resulting into educational process more expensive. Most household depends on their children during pick times of agriculture in their gardens and school attendance become more victimized leading to poor or no attendance at all [26]. This study was therefore focused on differences in educational environments between rural and urban institutions in Malawi focusing on both primary and secondary education.

\section{Literature Review}

The researcher's investigation seeks to bridge the gap which exists among the urban and rural educational institutions, scholars and teachers. Such differences have resulted into the government failure to fulfil its educational policy of equal education for all. Kadzamira and Rose [13] suggests that there are 
some undiscovered elements which contributes to low school attendance and performance. Malawi National Educational Policy [10] have evidenced the failure of Malawi government in fulfilling its policy and wonder if it could fulfill its goal of providing education for all by 2010 for the second time. The findings of this investigation and its recommendations will act as a basis in achieving the 2030 intended educational goal and will fuel Malawi economic boom. Low educational enrolment is threatening the strategy of empowering Malawians in socio economic development participation. Mulkeen, [21] opines that failure to attain school encourages unemployment and urbanizations, a tendency which collapses country's status. 2.0. Research approach: This research was designed to seek views from the rural and urban primary and secondary population on the scholastic variances of the two locations (rural and urban). According to Mason [18], Long and Godfrey [17], research seeking people's views, opinions, cultural understanding are qualitative by nature. The phenomilogical nature of the problem therefore determines the nature of its approach as recommended by Rodeo [12] and Yin [30]. The research is an interpretive by nature as categorized by Mason [18], Camilli and Elmore[4] and Mertler Charles [20]. Open ended and unstructured questionnaires were used to collect data though telephone interviews. Sounders et al [25] regards the interpretive research as an in-depth data collection because of its provision of probing where more information is attracted. The system provides firsthand information and can hardly be distorted by the third party or end user. Lester, [16] recommends qualitative research approaches because the collected information is based on the personal experience and perceptional phenomenon.

The researcher sampled five primary schools head teachers from each region of three (three from rural and two from urban settings) and two secondary schools from the same (one from rural and one from urban) totaling to twenty-one institutions. Names of primary schools sampled are: Itulo, Chinongo, Mughona, Kawale and Nachiwe (from the northern region); Lifuwu, Mtangombe, Chiputu, Chilinde and Mphungu (from the central region) and Chiwembe, Mbayani, Kachele,livilivi and Nsehe (from southern region). Secondary schools included the following: Namutegha and Chitpa from the northern region; Bwaila and Mvera (from the central region); H.H.I and Balaka (from the southern region). Random sampling was used to identify schools while purpose sampling was used to identify head teachers. Head teachers are more knowledgeable about institutions and scholars' challenges, hence the choice made for them to be participants.

\section{Statement of Problem}

Kadzamira and Rose [13], Banda [2] and UNESCO [28] states that there are gaps in Malawi which requires to be unveiled and bridged in order to fulfil its educational National strategy for education for all by 2020. However, the Malawi Educational

Monitoring Information System [8] contends that there are some undiscovered reasons which contributes to low or poor attendance and performance for the youth in Malawi educational system. Based on reports by Hodal and Holder [12], Malawi Education Policy [10] and NESP [22] Malawi government was unsuccessful to achieve its educational goal of education for all by 2015 . It is therefore evidenced that there is need for further investigation in order to fulfill the government's goal despite of time difference in its achievement. It is therefore imperative for the Malawi government to find means of improving its educational performance amongst the youth who are in the majority of its population. The findings will be used as a basis for government policy formation in order to improve developmental issues which are driven by competent and well-developed human capital.

\subsection{General objective}

The foremost objective of this study was to create conducive learning environment for both rural and urban primary and secondary learning institutions and learners. This was achieved by further investigation of the known and concealed issues contributing to poor or no attendance of both primary and secondary scholars.

\subsection{Specific Objectives}

The general objective was achieved by diversifying the following specific objectives 1 . To analyses the quality of teachers in both rural and urban institutions 2. To analyses the quality of infrastructures for both rural and urban institutions 3 . To investigate challenges faced by both rural and urban scholars 4. To establish mechanisms in promoting universal quality

education in both rural and urban primary and secondary settings.

\subsection{Research Question}

Hungler and Polit [24] have defined research question as an edict of a specific request for information the researcher want to respond in order to settle the challenge under investigations. The question bridges the existing gap in the intended investigation area. This research therefore longed to answer the following question: "To what extent does 
variation in teaching and learning environments affect quality of education attained". Research question therefore guide the investigator in concentrating on the envisioned theme and develops the whole enquiry procedure [7].

\subsection{Sub Research Questions}

For a statement of the problem to make sense during the investigation process, there was need to develop sub research questions as opined by Choga and Njaya [6]. The role of research questions asks what is associated amongst variables of divergences during the process of investigation. This is in contrast to a hypothesis which foretells the associations among variables. Research questions therefore describes the stated research problem or challenge and specifies variables of the research [18]. Therefore, this research pursued to give response the subsequent questions: 1. What differentiates among rural and urban teachers? 2. Whose responsibility is it in erecting school infrastructures in both rural and urban settings 3 . What challenges do scholars face in rural and urban schools 4 . How are primary and secondary scholars motivated to attend school.

\subsection{Responses from Primary Head Teachers}

Q. 1: Tell me about your school composition.Most rural head teachers had the following responses. There are an average of three thousand pupils per year against four qualified teachers and three un-qualified teachers, totaling to seven with an average classroom of five. The school have three staff houses and no office block. Head teachers from urban institutions had a different scenario where all teachers averaging to thirty were qualified ones with an average of five thousand pupils. There was an average of twenty classrooms with only one house for the head teacher.

Q. 2: What is the nature of school infrastructures? - Most rural infrastructures were built of clay and burnt bricks, smeared walls and floors with the same clay. Some were roofed with iron sheets while others were of grass thatched. Parents were responsible for the erecting and maintenance of all school infrastructures.

Urban head teachers responded differently from those of rural. Infrastructures are erected by the local authority (city council or town council) but maintenance becomes the institutional roll. All infrastructures are made up of either cement blocks, burned bricks and iron sheets roofed. Walls are cement plastered. Lavatories are provided with piped water. Most infrastructures have electricity facilities.
Q. 3: What are the scholar's barriers to their education? - Several factors were mentioned in response to this question by the rural and urban institutions:

\section{i. Rural Institutions}

- Long distance to and from school for an average of six kilometer in total with empty stomach;

- Involvement of farming activities in support of their parents;

- Poverty which deprives scholars needs such as notebooks, pencils and exercise books;

- Schools' activities such as collection of teaching and learning materials from educational centers of ten kilometers away;

- Involvement in school fundraising activities like;

- piece of works which enables institutions to buy sporting equipment's and uniform;

- Floods which inhibit young scholars in crossing big and tough rivers as well as streams.

\section{ii. Urban Institutions}

- Involvements with indoor social media like television

- Outdoor Entertainments such as weddings, discos and football games

- Pocket money for break time usages

Q. 4: How do you rate the performance, drop outs and failures of pupils? - Rural institutions registered more dropouts and failures than those in the urban institutions.

Q. 5: How comfortable are rural teachers in terms of rural environments? - Most reliable and well qualified and experienced teachers ask for transfers to teach in urban areas or they resign based on the negative response they get from the authorities.

\subsection{Questions for secondary school head teachers}

Q. 1: What is the status of your institution? - Most institutions were none borders except few which has boarding facilities. All institutions were of both male and female student but all subjected to variation of tuition fee amounts. Those in cities had higher tuition than rural ones. Students who come from far away organize themselves in paying slums turning them into self-boarding. Some institutions have provision of accommodation for female students only who operates in an organized manner by their institutions.

Q. 2: What are some challenges for your scholars? - i. Accommodation for those from far distances; ii. School requirements such as stationery and uniform; 
iii. Dropouts due to family's poverty challenges and iv. Lack of parental care while away from parents compels some students in indulging themselves in immoral and drug abuse.

\section{Analysis of Findings}

Q.1: School composition - Rural primary schools have qualified teacher pupil ration of 1:750 but is alleviated by un-qualified teachers of three, reducing the ratio of teacher pupil to 1:430. This is ungovernable class situation by any eligible teacher because of the following: The number of pupils cannot fit into one classroom at a time. Such situations force the responsible teacher to group pupils into manageable class of more than one. By so doing, the responsible teacher will have to teach for the whole day and have no time to plan for the following or next lesson or class. Large group of pupils in a class limit some pupils to be fully engaged in groups or class discussions creating a gap amongst them in knowledge sharing and gaining [15]. According to the findings, only three teachers have their houses within the school compass. This means that other teachers are renting outside their institution where means of transport is limited to walking with a lot of fatigue created to limit them from preparing before next class session. In a rural setting, quality housing for renting is questionable. It is without doubt that such teachers face challenges with vulnerable houses they rent such as: Leakages, security and at times noise within and around their rented homes. Through probing questions, the researcher learned that all infrastructures in rural educational institutions are initiated by local community who have extremely limited resources hence producing substandard housing and classroom blocks which are vulnerable to heavy rains, wind. Untrained teachers are engaged by the local community who are also responsible for paying them a wage below minimum wage prescribed by the government. The un-trained teachers and expected quality education is quite retroactive. According to Balaban [3], teachers must have a heart of children's care with quality materials, academic being the uttermost. Balaban, reiterates that a good teacher requires to be equipped first before engaging him or her into sharing knowledge gained to children for fear of "liking pupils" which may have a permanent damage on them.

Urban head teacher's response was different from those of rural. All teachers were qualified civil servants who were engaged by the government. All infrastructures are initiated by the local authority (city, town councils or municipality). School infrastructures are sound and pauses less threats to both learners and teachers. Only the head teacher is provided a house within the school premises while the rest can easily find renting houses of their choice.
An average teacher pupil ration is $1: 166$. Though the ratio is still high but lower than that of the rural. Urban institutions have more manageable number of pupils per class than those of the rural. The urban has more number of classrooms as compared to the rural. Urban classroom may be conducted in parallel because they have enough space and more number of teachers. There are no un-trained teacher taking part in teaching. The quality of teachers can greatly affect the quality of outcomes at the same time impacting the degree of countries economic growth.

Q. 2: What is the nature of school infrastructures? - Most of rural infrastructures were built of clay burnt bricks, floor and wall smeared with clay but iron sheet roofed at times with some leakages. Few of them were grass roofed and cleated a lot of threat to learners in a form of wet surfaces due to roof leakages or dusty floor both being health hazard agents to several diseases. Glass roofed structures are also vulnerable to fire which may cause permanent damage to property as well as to lives. Urban infrastructures are of high standard, built of cement locks, burned bricks, cement mortar, well plastered and floored. The challenge learned is maintenance responsibility which remains in the hands of the institution with limited or no resources. Urban infrastructures have services such as water and electricity which promotes health and hygiene elements contrary to rural ones [5].

Q. 3: What are the scholar's barriers to their education? - Most rural primary schools are at a wide distance apart (between two to six kilometers). The distance from homes to such schools' limit pupils start their education after attaining at least seven to eight years. This is so because there are no means of transport to and from school, a situation which compels all to walk such long distances. Pupils therefore have to be strong enough to be able to cross some rivers which have no bridges at all and pauses great threat to all ages during rainy seasons. Most of the rural pupils are from parents living below poverty line and have no opportunity to have three meals a day but one. Therefore, most pupils walk long distances to and from schools with empty stomachs.

Many rural parents/guardians are illiterate and does not value education much as a result they (parents/guardians) force their wards to join them in their gardens during farming pick times. By doing so, children absent themselves from attending lessons for a period of three months on average. Poverty deprives most pupils from accessing schools' requirements such as school uniforms, exercise books, notebooks, pencils, and ballpoints and finds learning difficult and embarrassing.

Most rural areas have no road networks to link primary schools. Even if there are some networks, 
are only useful during dry season where roads become passable. Most rural roads are not tar marked ones but graveled. Therefore, teaching and learning materials from educational centers are transported by pupils covering distances of ten kilometers on average. Should there be need for one teacher to be transferred to another school, children of that particular school where the teacher is transferred to be mandated to carry the belongings of the teacher on transfer on their heads due to scarcity of transport means. The act as transporters by using their physical heads and legs by literally walking while head loaded but for free. Sporting requirements such as footballs, net balls, uniforms for sports are organized and purchased though joined local pieces of works by pupils (joint fundraising which is in most cases worked in people's gardens). By so doing, classes are suspended until such a goal or goals are accomplished.

The researcher had contrary views from urban institutions. Most pupils are from working class parents or guardians and are able to support their children in school requirements. Above all, most urban parents and guardians have some education and values children's education much better than those in the rural. Therefore, children engage in indoor social media such as television, football, games and so on during their free time. From the observations, urban pupils have more free time than those from the rural and this may be a contributing factor in school activity concentrations and achievements. Since most urban guardians and parents are either working or business oriented, do have day to day food for their children and possibly misses no meal and as such concentrates on education without hunger disruption [11].

Q. 4: How do you rate the performance, dropouts and failures of pupils? - The researcher observed more dropout children in rural settings than in urban schools. The research suggests that the variation in educational environments is the major contributing factors. Starting school at the age of eight is a bit too late and worse enough, those children are not exposed nor privileged to any nursery or kinder garden to first learn to familiar with others as a community before primary schools. Urban children are subjected to nursery school not that all parents support it (for is more expensive) but finds in easier for their children to be taken care of while they are at work or business.

Q. 5: How comfortable are rural teachers in terms of rural environments? - The researcher learned that competent and well experienced teachers opt to work in urban areas rather than rural. After a probing question on reasons for longing in urban schools, the following were the responses: Rural schools have challenges in accessing teaching and learning requirement, Rural areas has great transportation challenge because of poor or no road network to allow them access life necessities, there are no or equipped health services to serve human live and that rural teachers have no hardship allowance as a consolation. Most of the rural institutions are limited to access some services like electricity which is a source of network for internet. Being barred from internet is less like being denied of human right to information. Handworkers in both rural and urban are not recognized in terms of motivational factors such as promotion, material incentives and scholarships. Both poor and best performers are treated equally, a situation which is demoralizing the able ones. Therefore, rural schools have less experienced and qualified teachers than those in the urban setting. This variation in quality of teaching staff greatly affects scholar's attitude and performance. Teaching is an academic instructional process to learners from their source/s. Dynamic schooling arouses scholar's interests and accomplish their desired goals. Poor academic instructional process demoralizes scholars and greatly contributes to their diminishing interest in education as a whole [14].

\subsection{Secondary school head teacher's responses}

Q. 1: What is the status of your institution? Malawi secondary schools are both of urban and rural. Most urban and rural secondary schools are day schools whereby students operate from their homes and attend lessons during daytime only. Few are boarding which accommodate students in school for the set period of time. However, there are also semi boarding secondary schools where boarding facilities are provided to students but minus food and beds. The research finding was that most secondary schools were no boarders. The researcher perceives that boarding schools are much more suitable in rural areas where students travel long distances and cannot daily commute from homes. They require boarding facilities in full through expensive to manage. Urban students operate within their homes vicinity and may not require boarding as compared to those in rural settings. This is a challenge as per observations above that most rural parents/guardians live below poverty level and faces challenge to manage boarding requirements for their wards while those of the urban are more financially able than those of the rural and yet exposed to cheaper educational opportunities than those of the rural. Therefore, balancing the two is a challenge.

Students who come from far to a selected secondary school where boarding requirements are expensive or are not there, students organize themselves by identifying a paying slum where they have a self-boarding as they attend to school lessons. 
Such circumstances require well-disciplined students to withstand school obstacles which takes advantage of their poor status especially to lady student who are more vulnerable as compared to men because they have none to control them but themselves. This is different from full boarding environment where school management takes all students responsibilities to include: safety, health, social, and academics issues.

Q. 2: What are some challenges for your scholars? - Most respondents highlighted accommodation as the major challenge to students. They belief boarding contributes to education concentration by both teachers and students. Some indicated that boarding students are more disciplined because they are bound by management regulations and law breakers are suspended or expelled from school. They compared with day schooling as free range, un-controllable and poorer performance as compared to those in boarding schools. Most dropout were experienced in more remote areas as compared to those within the vicinity of towns, cities and municipalities. The researcher assumes that health facilities must be one of the contributing factors of dropouts since sick student cannot travel long distance to attain education and could opt to nature his or her life rather than worsening the situation with long school travels.

The researcher concludes that students who travel long distances to attain education each and every day and those who organize their own self boarding are more subjective to immoral behaviors, Drug abuse, and poor class performance and unhealthier due to poor or inconsistent diet for they lack parental care, love and guidance.

\section{Recommendations}

The Government should put in place policies in order to create conducive teaching and learning environments through the following implementations:

- Train enough teachers and eliminate or upgrade all untrained teachers.

- All educational government infrastructures should be uniform in terms of quality and safety to users.

- Build primary schools to a proximity of not more than two kilometers from one another to ease scholar's movements.

- Provide road network to all learning institutions in order to relief scholars from being used as a transport means of school requirements.
- Government should introduce funds to support all primary schools with their sporting requirement in order to safeguard pupils from being used as income generators through exploiting piece work.

- Create provisions for educational partners to support learning institutions.

- Provide reliable and well stocked health centers for ease of access by scholars, teachers and parents.

- Provide equal teacher support services for their effective teaching for both rural and urban.

\section{Conclusion}

The paper has highlighted issues concerning variances in learning environments between rural and urban institutions. The said variations contribute greatly to the underperformance of scholars and quality of education in general. There are no adequate teaching and learning equipment and tools in most rural institutions as compared to the urban ones .Poor road network contributes to hardship scholar's face in rural educational institutions. Unqualified teachers only help to distort the system rather than building it for the good of the nation. Widely spaced rural institutions compels some scholars to stop schooling due to physical challenges such us floods and biological ones such as poverty. By leaving the responsibility of educational infrastructures in the hands of local and financially challenged community is less like promoting poor quality of educational environment rather than promoting it through great support.

\section{References}

[1] Adedeji, S.O. and Bamidele, R.O. (2003). Economic Impact of Tertiary Education on Human Capital Development in Nigeria. In Human Resource Development in Africa. Ibadan; The Nigerian Economic Society. Selected Papers for 2002 Annual Conference.

[2] Banda, D.M. (2003). Gender and Education for All: The Leap to Equality. Gender sensitive educational policy and practice: the case of Malawi. [Online] Available from: http://unesco.org (Access date: 15th May 2013).

[3] Balaban (1992). The Investigation of the Level of SelfDirected Learning Readiness According to the Locus of Control and Personality Traits of Preschool Teacher Candidates International Electronic Journal of Elementary Education 8(3):391-402.

[4] Camilli ,G. Brenner, M. E. (2006). Interviewing in Educational Research. In J. L. Green, Camilli,G. and P. B. Elmore (Eds.), Handbook of complementary methods in 
education research (p. 357-370). Lawrence Erlbaum Associates Publishers.

[5] Cheng, Yeun Cheong (2013). "Classroom Environment and Student Affective Performance: An Effective Profile." The Journal of Experimental Education, Vol. 62, No. 3 (spring, 1994), pp. 221- 239. Accessed November 6, 2013.

[6] Choga, F. and Njaya, T. (2011). Business Research Methods. Harare: Zimbabwe Open University.

[7] Cormack D.F., Benton DC (1996) Asking the research question. In Cormack DF (Ed) The Research Process in Nursing. Third edition. London, Blackwell Science.

[8] EFA and MDG (2009). Global Monitoring Report. Retrieved March 19, 2010 http://www.inruled.org/en /templet/default/ShowArticle.jsp?id=1129.

[9] Frederik Cornillie,StevenL. Thorne and Piet Desmet (2012). Recall special issue: Digital games For language learning: challenges and opportunities. ReCALL, 24, pp 243-256, doi:10.1017/S0958344012000134.

[10] Government of Malawi (GoM) (December, 2007): District Education Plan, (All Education Districts), Ministry of Education, Science and Technology Hanushek (2011). 'The economic value of higher teacher quality', Economics of Education Review, Vol 30, pp 466-479.

[11] Hayden, M., and Martin, R. (2013). Recovery of the education system in Myanmar. J. Int. and Comp. Educ., 2(2), pp 47-57.

[12] Hodal, K. and Holder, J. (2016). Poorest countries hit hardest as world lags behind on global education goals. The Guardian, 6th September. p.1. (www.the guardian.com/global development/2016/sept/06 (Access Date: 15 August, 2017).

[13] Kadzamira, E. and Rose, P. (2003). 'Can Free Primary Education meet the needs of the poor? Evidence from Malawi'. International Journal of Educational Development, 23(5) pp.501-516.

[14] Khan and Ghosh (2016). Analyzing the impact of poor teaching on student performance. International Conference of Teaching, Assessing and Learning for Engineering. Doi: 10:1109/TALE.2016.7851789.

[15] Krueger (2003). "Economic considerations and class size" Economic Journal, Royal.

[16] Lester, S. (1999). An introduction to phenomenological research. http://www.sld.demon.co.uk/ resmethy.pdf (Access Date: 2 April, 2013).

[17] Long, A. and Godfrey, M. (2004). An evaluation tool to assess the quality of qualitative research studies. International Journal of Social Research Methodology, 7(2), pp. 181-19.

[18] Mason, J. (2002). Qualitative Researching. 2nd Ed. London: Cromwell Press.
[19] MDGs (2010). The challenge of intersecting inequalities. Naila Kabeer for Institute of Development Studies.

[20] Mertler, A.C. and Charles, C. M. (2005), Introduction to Educational Research. 5th Ed. Pearson Education. Library of the Congress.

[21] Mulkeen, A. (2005). Teachers for rural schools: a challenge for Africa. Working document prepared for the Ministerial Seminar on Education for Rural People in Africa: Policy Lessons, Options and Priorities. Addis Ababa, Ethiopia, 7-9 September 2005. World Bank: Africa region.

[22] NESIP. (2008-17). A statement: Ministry Education, Science and Technology of Malawi. http://planipolis.iiep. unesco.org/upload/Malawi/Malawi_NESP.pdf. (Access Date: 17 August, 2015]

[23] Ordonez, V. (2011). Rural education: Changing environments; emerging challenges, policy perspective and option. Shangai: UNESCO.

[24] Polit and Hunngler (1999). Homelessness, Housing, and Mental Health: Finding Truths, Creating Change. Canadian Scholars Press, Toronto.

[25] Saunders et al. (2003). Research Methods for Business Students. Pearson Education Limited. Edinburgh Gate, England. Sida, (2006). Fighting Poverty in Urban World-Support to Urban development.

[26] Taylor, Peter and Mulhall, Abigail (2001). 'Linking learning environments through agricultural experience enhancing the learning process in rural primary schools'. International Journal of Educational Development, 21, 135-148.

[27] UNESCO (2005). Education for All. Global Monitoring Report: The quality imperative. EFA global monitoring report. Paris: UNESCO.

[28] UNESCO. (2007). Education for All Global Monitoring Report. http://www.icde.org/UNESCO+Education+for+All+Global+Monitoring+Report+2008.b7C_wtb U0V.ips (Access Date: 18th August, 2015).

[29] UNDP (2008). Human Development Report 2007/2008. New York: Palgrave Macmillan.

[30] Yin, R. K., (1994). Case Study Research Design and Methods: Applied Social Research and Methods Series. Second Edition. Thousand Oaks, CA: Sage Publications Inc. 